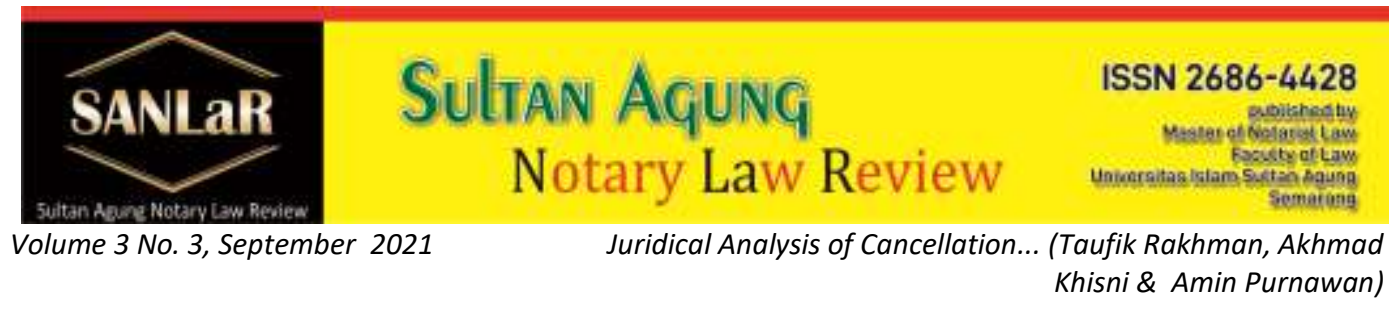

\title{
Juridical Analysis of Cancellation of Bonding Agreements of Selling \& Buying a Plan of Land
}

\author{
Taufik Rakhman*), Akhmad Khisni ${ }^{* *}$ and Amin Purnawan ${ }^{* * *}$ \\ *) Faculty of Law, Universitas Islam Sultan Agung (UNISSULA) Semarang, E-mail: \\ rafi86.tr@gmail.com \\ ${ }^{* *}$ Faculty of Law, Universitas Islam Sultan Agung (UNISSULA) Semarang, E-mail: \\ amin.p@unissula.ac.id \\ $\left.{ }^{* * *}\right)$ Faculty of Law, Universitas Islam Sultan Agung (UNISSULA) Semarang, E-mail: \\ khisni@unissula.ac.id
}

Abstract. The purpose of this study was to determine and analyze the process of canceling the binding sale and purchase agreement for a plot of land. To find out and analyze the legal consequences of the cancellation of the binding sale and purchase agreement for a plot of land in the construction of legal certainty. The method used by the researcher is Juridical Empirical (sociolegal research)and The specifications in this study are descriptive analytical. Based on the results of the study that The process of canceling the binding sale and purchase agreement for a plot of land is made by the parties to make their own cancellation deed in carrying out any legal actions, all possibilities can occur, including if the parties have agreed to cancel the previously agreed sale and purchase agreement, through a court order to cancel the agreement that is not Legal consequences can only be carried out by a judge or higher institution or competent institution, automatically canceling the agreement, then the contents of the agreement are automatically null and void by law and even considered that the agreement never existed or never occurred. Legal consequences Against the cancellation of the binding agreement on the sale and purchase of a plot of land in construction, legal certainty, namely:null and void by law, namely the non-fulfillment of objective conditions (Article 1320 of the Civil Code): a certain matter, a permissible/halal/legal cause, the agreement cannot be executed, because the agreement is not simply canceled, but cannot be implemented or forwarded to the next process, because it is still have a certain legal status.

Keywords: Cancellation; Sale; Purchase; Binding; Agreement; Land. 


\section{Introduction}

The binding sale and purchase is a form of agreement that arises from the legal needs that develop in society. The binding sale and purchase of land is an anonymous agreement, because it is not found in the forms of agreements regulated in the Civil Code. The binding agreement for the sale and purchase of land is an implementation of the principle of freedom of contract, where the parties can freely determine their will.

Sale and purchase is a form of agreement that gives birth to an obligation or an agreement to provide something, which in this case is manifested in the form of delivery of objects sold by the seller and delivery of money by the buyer to the seller. ${ }^{1}$ Proof of a right owned by a person, either a land or building, or in the implementation of giving land to another party by exchanging or selling it requires a deed.

From this point of view, the implementation of the binding sale and purchase of land becomes interesting to study further considering that the binding sale and purchase agreement is a legal act that precedes the process of transferring land rights. As a form of engagement, the land sale and purchase binding agreement contains the rights and obligations of the parties who made it, so that if the things that have been agreed upon in the sale and purchase binding deed are violated or not fulfilled by the parties who made it, then it can be said to have happened. default.

This situation is certainly not profitable or can even harm the parties who buy and sell land rights, because it makes the seller have to postpone the sale of the land. Against the buyer, causing delays in his desire to get the rights to the land to be purchased. How to overcome this and for the smooth orderly administration of land, a legal innovation was found, namely the making of a Deed of Sale and Purchase Binding Agreement (PPJB), although the contents were about buying and selling, but the format was only limited to a binding agreement for the sale and purchase of land rights which was carried out before a Notary. Notary as a public official who has the authority to make various kinds of agreements. ${ }^{2}$

The implementation of the sale and purchase binding agreement does not always run smoothly, sometimes there are factors that make the binding unable

\footnotetext{
${ }^{1}$ Gunawan Widjaja dan Kartini Muljadi, Seri Hukum Perikatan Jual Beli, Raja Grafindo Persada, Jakarta, 2003, p. 7.

${ }^{2}$ Habib Adjie, Hukum Notaris Indonesia, Refika Aditama, Bandung, 2008, p. 77-78
} 
to continue or even until the deed becomes void, including: ${ }^{3}$

"Due to the non-fulfillment of timely payments made by the buyer to the seller, which in the end the agreement made by the parties ended up being invalidated because it had passed the agreed grace period, the seller sold the land to another party, there was an agreement from the parties, because the conditions were void as stated in the agreement. stated in the sale and purchase binding clause has been fulfilled, as well as the cancellation by the Court of a lawsuit from one of the parties which is usually caused by a default by one of the parties and there is an element of unlawful action that results in the cancellation of the PPJB deed.

From the problems described above, the objectives to be achieved in this study are: To find out and analyze the process of canceling the binding sale and purchase agreement for a plot of land. To find out and analyze the legal consequences of the cancellation of the binding sale and purchase agreement for a plot of land in the construction of legal certainty.

\section{Research Methods}

The method used in this paper is empirical juridical. The specifications used in this study are descriptive analytical. ${ }^{4}$ The sources and types of data in this study are primary data. And secondary data obtained from literature studies related to the theory of legal certainty and legal protection.

\section{Results and Discussion}

3.1. The Process of Cancellation of the Sale and Purchase Agreement for a Plot of Land

The legal action that results in the transfer of land rights and must be registered behind the name is a legal act of buying and selling where the deed is made in the AJB made by the PPAT which is commonly referred to as AJB transfer of name, the $A J B$ is then used as a registration tool for the transfer of land rights. ${ }^{5}$ related to the sale and purchase agreement of land ownership rights, the seller transfers the ownership rights to the land to the buyer who has previously been determined and in accordance with the agreement agreed and included in

\footnotetext{
${ }^{3}$ T. Baswedan, “Kajian Yuridis Pembatalan Akta Pengikatan Jual Beli (PJB) Tanah Yang Dibuat Dihadapan Notaris", Premise Law Journal, Universitas Sumatera Utara, Vol 4, 2014, p. 16.

${ }^{4}$ Soerjono Soekanto \& Sri Mamuji, Penelitian Hukum Normatif suatu tinjauan singkat, Jakarta: Raja Grafindo Persada, 2001, p. 43

${ }^{5}$ Sumardi, "Kedudukan Kuasa Menjual Atas Dasar Surat Keterangan Notaris Tentang Pembayaran Lunas Dalam Pembuatan Akta Jual Beli Balik Nama." Acta Comitas, p.2
} 
the sale and purchase agreement. The agreement is related to Article 1320 of the Civil Code concerning the legal requirements of an agreement that determines ${ }^{6}$

An agreement that is canceled because of a request from the party who wants it, namely the parent, guardian, or guardian is said to be a relative cancellation or non-absolute cancellation, which can be divided into: ${ }^{7}$

a. Regarding the cancellation by filing a lawsuit to the judge. (Article 1446 of the Civil Code);

b. Cancellation by the judge through a decision, (Article 1449 of the Civil Code).

The binding sale and purchase agreement is actually no different from the agreement in general. It's just that the sale and purchase binding agreement is an agreement that was born due to the open nature of Book III of the Civil Code (KUHPer), which provides the widest freedom for legal subjects to enter into agreements containing anything and in any form, as long as does not violate laws and regulations, public order and decency. The sale and purchase binding agreement was born as a result of the obstruction or the presence of several requirements determined by the law relating to the sale and purchase of land rights which ultimately hampered the settlement of transactions in the sale and purchase of land rights. Some of these requirements arise from existing laws and regulations and some arise as an agreement between the parties who will buy and sell land rights. Requirements arising from the law, such as buying and selling, must be paid off before the Sale and Purchase Deed can be signed. ${ }^{8}$

The sale and purchase binding agreement was born as a result of the obstruction or the presence of several requirements determined by the law relating to the sale and purchase of land rights which ultimately hampered the settlement of transactions in the sale and purchase of land rights. Some of these requirements arise from existing laws and regulations and some arise as an agreement between the parties who will buy and sell land rights. Requirements arising from the law, such as buying and selling, must be paid off before the Sale and

\footnotetext{
${ }^{6}$ Dewi, R. P., \& Purwadi, H, Pembatalan Akta Perjanjian Pengikatan Jual Beli Akibat Wanprestasi (Studi Kasus Putusan Nomor: 200/Pdt. G/2012/PN. Jkt.Sel). Jurnal Repertorium, 4(2).2017, p.144

${ }^{7}$ Projodikoro, W, Asas-Asas Hukum Perjanjian. Sumur. Bandung, 2003, p. 121

${ }^{8}$ Dewi Kurnia Putri, Amin Purnawan, Perbedaan Perjanjian Pengikatan Jual Beli Lunas Dengan Perjanjian Pengikatan Jual Beli Tidak Lunas, Vol. 4 No. 4 December 2017, Jurnal Akta Unissula
} 
Purchase Deed (AJB) can be signed. In general, the requirements that often arise are requirements that are agreed upon by the parties who will make a sale and purchase, for example at the time of buying and selling, ${ }^{9}$

The content of the binding sale and purchase agreement which is a preliminary agreement for the birth of the main agreement is usually in the form of promises from the parties containing provisions on the agreed terms for the validity of the main agreement. For example, in the binding agreement for the sale and purchase of land rights, the clause of the agreement usually contains promises from both the seller of the land rights and the buyer regarding the fulfillment of the conditions so that the main agreement, namely the sale and purchase agreement and the sale and purchase deed, can be signed in front of the owner. Land Deed Making Official (PPAT), such as a promise to manage land certificates before buying and selling is carried out as requested by the buyer, ${ }^{10}$

In addition to the usual promises in the sale and purchase agreement, it also includes the right to give power of attorney to the buyer. This happens if the seller is unable to attend signing the sale and purchase deed before the Land Deed Maker Official (PPAT), either because of the remote location, or because there are obstacles and so on. And the granting of power of attorney usually only takes effect after all the conditions for buying and selling land rights at the Land Deed Making Officer (PPAT) have been fulfilled. ${ }^{11}$

In the regulations regarding land rights, among others are the Basic Agrarian Law (UUPA), Government Regulation Number 40 of 1996 concerning Cultivation Rights, Building Use Rights and Land Use Rights, Regulation of the State Minister of Agrarian Affairs Number 3 of 1997 concerning provisions for the implementation of Government Regulations. Number 24 of 1997 and others, are expressly regulated for every legal action related to land rights, meaning that everyone who will take legal actions related to land rights must comply with all regulations relating to land rights. For example, in the case of buying and selling land rights, where in Government Regulation Number 24 of 1997 concerning

\footnotetext{
${ }^{9}$ Rusdianto, Dony Hadi, Beberapa Catatan Penting Tentang Pengikatan Jual-Beli Hak Atas Tanah, Mitra Ilmu, Rineka Cipta, Jakarta, 2009, p. 41.

${ }^{10}$ Jaya Gunawan, Perkembangan Hukum Perdata Bidang Perjanjian Innominaat (Tak Bernama, Citra Ilmu, Bandung, 2010, p.10.

${ }^{11}$ Kamaluddin Patradi, Pemberian Kuasa Dalam Praktek Perjanjian Pengikatan Jual Beli Hak Atas Tanah, Gamma Press, Yogyakarta, 2010, p.20.
} 
Land Registration and Government Regulation Number 37 of 1998 concerning the Regulation of the Position of the Maker of Land Deeds (PPAT), ${ }^{12}$

The process of canceling the binding sale and purchase agreement for a plot of land is to make a deed of cancellation by the parties themselves, in carrying out any legal action, all possibilities can occur, including if the parties have agreed to cancel the previously agreed sale and purchase agreement. Through a court decision, the cancellation of an invalid agreement can only be carried out by a judge or higher institution or competent institution. Canceled by itself, as a result of the law of the cancellation of the agreement, the contents of the agreement by itself are also null and void by law and even considered that the agreement never existed or never happened. Many parties include exceptions to Article 1266 of the Civil Code to the agreement.

The process of canceling the binding sale and purchase agreement for a plot of land is analyzed using the theory of legal protection that is reflected in the sale and purchase agreement of property rights which is private law, but on the other hand land is an item of economic value, so there are often problems or defaults. To prevent this, the role of a notary is very important. Notaries are state officials who have the duty to provide legal protection to parties who take legal actions. For this reason, Notaries have the authority under the law to provide legal protection for parties who take legal action and avoid default.

\subsection{Legal Consequences for Cancellation of Binding Agreement for Sale and Purchase of Land in Construction Legal Certainty}

Indonesia is a country where most of the population live in agriculture (Agrarian) and Southeast Sulawesi is one of the regions in Indonesia Land is a very important factor for the survival of the community and the development of a nation. The importance of land for human life is something that cannot be separated because human survival to obtain food mostly comes from land management. ${ }^{13}$

As a legal act, the sale and purchase of land and building rights must be carried out in the presence of a Land Deed Maker Official (PPAT) and realized in a Sale and Purchase Deed (AJB). The existence of AJB and PPAT as evidence has fulfilled the clear and real nature which is a condition for the validity of the legal action in

\footnotetext{
${ }^{12}$ Fransiska Mayasari, Munsyarif Abdul Chalim, Tinjauan Yuridis Pelaksanaan Perjanjian Pengikatan Jual Beli Hak Atas Tanah Berdasarkan Akta Notaris Di Tegal, Vol. 4 No. 4 December 2017, Jurnal Akta Unissula

13 Hasmawati Halim, Effectiveness of Control of Deep Agricultural Soil on Enrollment Perspective, Volume 3 No.1, March 2021, Jurnal Sultan Agung Notary Law Review
} 
question, so that according to law it is binding on the parties who do it. ${ }^{14}$

Basically, the sale and purchase agreement (agreement to sell) is different from the sale and purchase agreement. PPJB is a sale and purchase of objects where the parties agree that the ownership rights to the object will be transferred to the buyer at some time in the future. While the sale and purchase agreement is a sale and purchase in which the ownership rights to the object immediately transfer to the buyer. ${ }^{15}$

The legal construction of the Sale and Purchase Agreement which forms the basis for the Imposition of Income Tax (PPh) is the Income Tax Law Number 36 of 2008 Article 4 paragraph 2 letter $\mathrm{d}$. In this article it is clearly stated that income derived from the transaction of transfer of rights to land and/or buildings may be subject to final income tax. The level of Final Income Tax Article 4 paragraph 2 from the transfer of land and/or building rights in general is $5 \%$. While the object of tax is income derived from the transaction. 2). The implementation of the sale and purchase agreement of land rights relating to the imposition of income tax (PPh) must be carried out clearly, namely based on the agreement of both parties, and carried out with the PPAT deed, in this case the sale and purchase deed $(A J B),{ }^{16}$

Based on the results of the research above, the legal consequences of the cancellation of the binding agreement for sale and purchase of a plot of land in the construction of legal certainty are: null and void, namely the non-fulfillment of objective conditions (Article 1320 of the Civil Code): a certain thing, the cause is permissible / halal / legal. The agreement cannot be implemented, because the agreement is not simply canceled, but cannot be implemented or forwarded to the next process, because it still has a certain legal status.

Legal Consequences on Cancellation of Binding Agreement for Sale and Purchase of Land in Construction Legal certainty is analyzed using the theory of legal certainty that there are three legal objectives, namely expediency, certainty, and justice. In carrying out these three legal objectives, the principle of priority must be used.

\footnotetext{
${ }^{14}$ Boedi Harsono, Hukum Agraria Indonesia:Sejarah Pembentukan Undang-Undang Pokok Agraria:Isi dan Pelaksanaan, Djambatan, Jakarta: 2003, p. 307.

${ }^{15}$ Abdul Kadir Muhammad, Hukum Perjanjian, Alumni, Bandung,1980, p. 243.

${ }^{16}$ Alannuari Afid Amasi, Akhmad Khisni dan Amin Purnawan, Juridical Review of Income Tax Restitution (PPH) against Cancellation of Sale and Purchase Agreement Based on Government Regulation Number 34 of 2016 Volume 3 No. 1, March 2021, Jurnal Sultan Agung Notary Law Review
} 


\section{Closing}

Based on the results of research and discussion in the previous chapter, it can be concluded that: a) The process of canceling the binding sale and purchase agreement for a plot of land is to make a deed of cancellation by the parties themselves, in carrying out any legal action, all possibilities can occur, including if the parties have agreed to cancel the previously agreed sale and purchase agreement. Through a court decision, the cancellation of an invalid agreement can only be carried out by a judge or higher institution or competent institution. Canceled by itself, as a result of the law of the cancellation of the agreement, the contents of the agreement by itself are also null and void by law and even considered that the agreement never existed or never happened. Many parties include exceptions to Article 1266 of the Civil Code to the agreement. B) Legal Consequences Against Cancellation of Binding Agreement for Sale and Purchase of a Land in Construction Legal certainty, namely: null and void, namely the nonfulfillment of objective conditions (Article 1320 of the Civil Code): a certain thing, the cause is permissible / halal / legal. The agreement cannot be implemented, because the agreement is not simply canceled, but cannot be implemented or forwarded to the next process, because it still has a certain legal status.

\section{References}

Journals:

[1] Alannuari Afid Amasi, Akhmad Khisni dan Amin Purnawan, Juridical Review of Income Tax Restitution (PPH) against Cancellation of Sale and Purchase Agreement Based on Government Regulation Number 34 of 2016 Volume 3 No. 1, March 2021, Jurnal Sultan Agung Notary Law Review

[2] Deen, Thaufiq., Ong Argo Victoria \& Sumain. (2018). Public Notary Services In Malaysia. JURNAL AKTA: Vol. 5, No. 4, 1017-1026. Retrieved from http://jurnal.unissula.ac.id/index.php/akta/article/view/4135

[3] Dewi Kurnia Putri, Amin Purnawan, Perbedaan Perjanjian Pengikatan Jual Beli Lunas Dengan Perjanjian Pengikatan Jual Beli Tidak Lunas, Vol. 4 No. 4 December 2017, Jurnal Akta Unissula

[4] Dewi, R. P., \& Purwadi, H, Pembatalan Akta Perjanjian Pengikatan Jual Beli Akibat Wanprestasi (Studi Kasus Putusan Nomor: 200/Pdt. G/2012/PN. Jkt.Sel). Jurnal Repertorium, 4(2).2017 
[5] Fransiska Mayasari, Munsyarif Abdul Chalim, Tinjauan Yuridis Pelaksanaan Perjanjian Pengikatan Jual Beli Hak Atas Tanah Berdasarkan Akta Notaris Di Tegal, Vol. 4 No. 4 December 2017, Jurnal Akta Unissula

[6] Hasmawati Halim, Effectiveness of Control of Deep Agricultural Soil on Enrollment Perspective, Volume 3 No.1, March 2021, Jurnal Sultan Agung Notary Law Review

[7] T. Baswedan, "Kajian Yuridis Pembatalan Akta Pengikatan Jual Beli (PJB) Tanah Yang Dibuat Dihadapan Notaris", Premise Law Journal, Universitas Sumatera Utara, Vol 4, 2014

Books:

[1] Abdul Kadir Muhammad, Hukum Perjanjian, Alumni, Bandung,1980

[2] Boedi Harsono, Hukum Agraria Indonesia:Sejarah Pembentukan UndangUndang Pokok Agraria:Isi dan Pelaksanaan, Djambatan, Jakarta: 2003

[3] Gunawan Widjaja dan Kartini Muljadi, Seri Hukum Perikatan Jual Beli, Raja Grafindo Persada, Jakarta, 2003

[4] Habib Adjie, Hukum Notaris Indonesia, Refika Aditama, Bandung, 2008

[5] Jaya Gunawan, Perkembangan Hukum Perdata Bidang Perjanjian Innominaat (Tak Bernama, Citra Ilmu, Bandung, 2010

[6] Kamaluddin Patradi, Pemberian Kuasa Dalam Praktek Perjanjian Pengikatan Jual Beli Hak Atas Tanah, Gamma Press, Yogyakarta, 2010

[7] Projodikoro, W, Asas-Asas Hukum Perjanjian. Sumur. Bandung, 2003

[8] Rusdianto, Dony Hadi, Beberapa Catatan Penting Tentang Pengikatan Jual-Beli Hak Atas Tanah, Mitra IImu, Rineka Cipta, Jakarta, 2009

[9] Soerjono Soekanto \& Sri Mamuji, Penelitian Hukum Normatif suatu tinjauan singkat, Jakarta: Raja Grafindo Persada, 2001

[10] Sumardi, "Kedudukan Kuasa Menjual Atas Dasar Surat Keterangan Notaris Tentang Pembayaran Lunas Dalam Pembuatan Akta Jual Beli Balik Nama." Acta Comitas 